Portland State University

PDXScholar

1984

\title{
The psychological intervention of group therapy for women coping with genital herpes
}

Susan D. Ferguson

Portland State University

Follow this and additional works at: https://pdxscholar.library.pdx.edu/open_access_etds

Part of the Diseases Commons, Psychoanalysis and Psychotherapy Commons, and the Psychology Commons

Let us know how access to this document benefits you.

\section{Recommended Citation}

Ferguson, Susan D., "The psychological intervention of group therapy for women coping with genital herpes" (1984). Dissertations and Theses. Paper 3296.

https://doi.org/10.15760/etd.3287

This Thesis is brought to you for free and open access. It has been accepted for inclusion in Dissertations and Theses by an authorized administrator of PDXScholar. Please contact us if we can make this document more accessible: pdxscholar@pdx.edu. 
AN ABSTRACT OF THE THESIS OF SUsan D. Ferguson for the Master of Science in Psychology presented November 16, 1984.

Title: The Psychological Intervention of Group Therapy for Women Coping with Genital Herpes

APPROVED BY MEMBERS OF THE THESIS COMMITTEE:

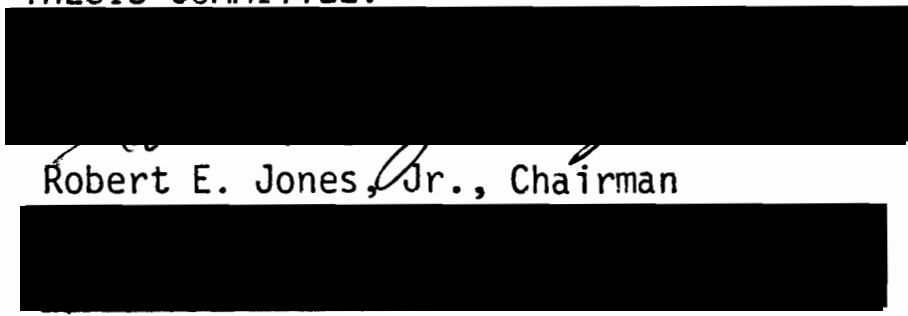

Patricia F. Hall

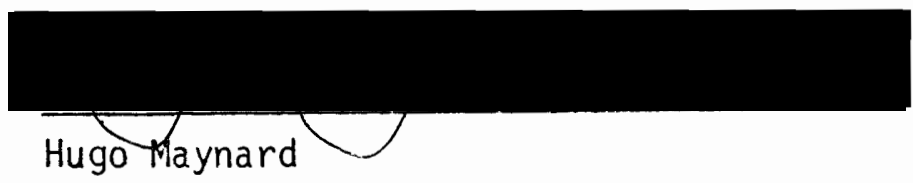

Three groups of women who had been diagnosed as having genitâl herpes completed a series of psychological assessments over the course of the four-month research period. One group received twohour weekly group psychotherapy sessions for eight consecutive weeks as a mode of treatment intervention. Two control groups were used for efficacy of treatment comparison. Ore control group consisted of regular members of a locâl self-help chäpter for herpes victims. The second control group was formed from those volunteers willing to participate, but who did not choose, or desire, any form of treatment. Outcome measures reflected a greater improvement in psychological adjustment following group therapy for the treatment group on depression, anxiety, and physical self-esteen as compared to the two control groups. Implications from the findings of this mode of therapy for genital herpes victims are reviewed and discussed. 
THE PSYCHOLOGICAL INTERVENTION OF GROUP THERAPY

FOR WOMEN COPING WITH GENITAL HERPES

\section{by}

Susan D. Ferguson

A thesis submitted in partial fulfillment
of the requirements for the degree of

MASTER OF SCIENCE

in

PSYCHOLOGY

Portland State University

1984 
TO THE OFFICE OF GRADUATE STUDIES AND RESEARCH:

The members of the Committee approve the thesis of

Susan D. Ferguson presented November 16, 1984.

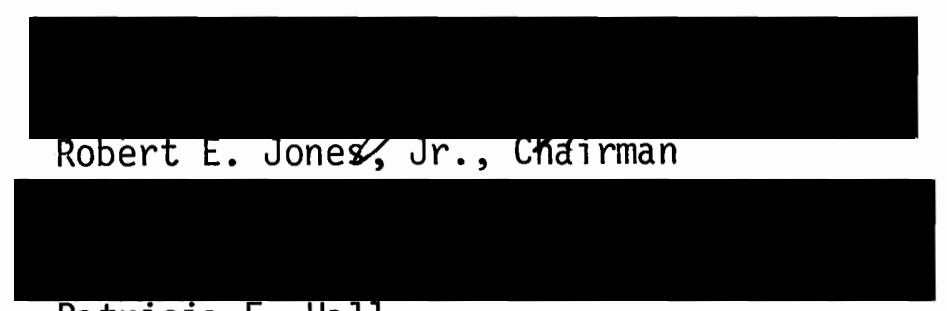

Patricia F. Hall

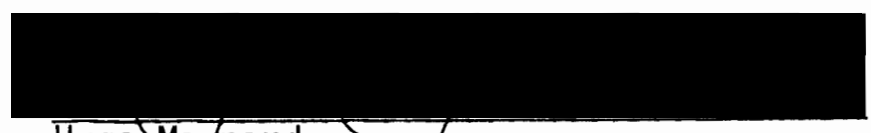

Hugo Maynard

APPROVED:

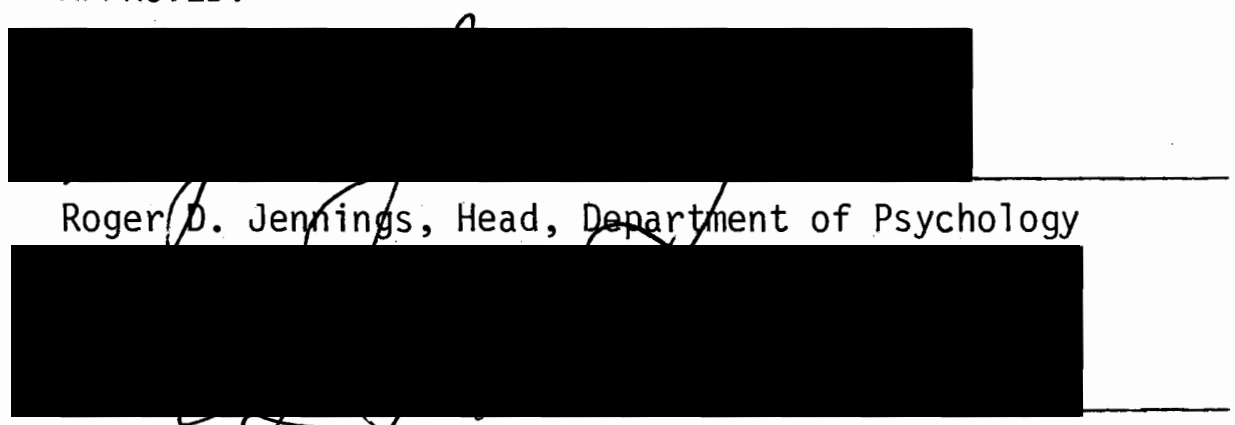

Jim F. Heath, Dean of Graduate Studies and Research 


\section{ACKNOWLEDGEMENTS}

I want to express my sincere appreciation and gratitude to all the people who made this research project possible. To my committee my thanks are extended for your patience, support, and guidance. To my chairman, Bob Jones, I want to thank you for your direction, assistance in coordinating the final details, and for your never-ending sense of humor which helped me avoid any extra panic as deadlines approached. To Hugo Maynard, my appreciation for your immediate responses within the time restraints I inadvertently placed upon you. Further, I welcomed your valuable comments and suggestions which made the final product that much better. To Pat Hall, I sincerely thank you for your patience, judgment, and for your willingness to supervise the work of a beginning clinician. Throughout the past several years, you have always extended sensitivity, offered advice, and support for all of my endeavors. You have shown me how to respect myself. I thank you.

To Adriane Gaffuri, my deepest affection and respect for your professional guidance, strict editorial comments, and encouragement. You have always believed in me which has helped me gain the self-confidence I needed to believe I can succeed. I thank you for your friendship.

And lastly, my gratitude and respect to all the women whose desire to grow and whose faith in my ability to help has made this research project reach fruition. I congratulate all of you for your courage and wish you continued and positive success. 
TABLE OF CONTENTS

PAGE

ACKNOWLEDGEMENTS ...............................

LIST OF TABLES ....................... v

LIST OF FIGURES ......................... vi

CHAPTER

I INTRODUCTION AND LITERATURE REVIEW . . . . . . 1

II METHOD ....................... 12

Subjects ................ 12

Materials................. 13

Procedure............. 14

III RESULTS ........................... 26

Beck Depression Inventory........ 26

Multiple Affect Adjective Checklist .... 30

Tennessee Self Concept Scale ...... 33

IV DISCUSSION ....................... 38

REFERENCES ........................... 43

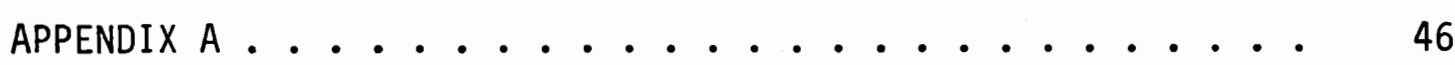

APPENDIX B ................................ 47

APPENDIX C .............................. 50

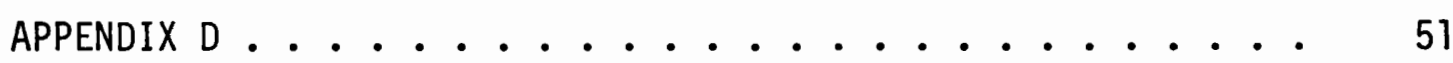




\section{LIST OF TABLES}

TABLE

I Means and Standard Deviations for Group Therapy, Self-Help Control, and No Treatment Control Groups on the Beck Depression Inventory . . . . . . .

II Means and Standard Deviations for Group Therapy, Self-Help Control, and No Treatment Control Groups on the Multiple Affect Adjective Checklist . . . . 31

III Means and Standard Deviations for Group Therapy, Self-Help Control, and No Treatment Control Groups on the Tennessee Self Concept Scale ....... 34 


\section{LIST OF FIGURES}

FIGURE

PAGE

1 Mean Beck Depression Inventory Scores at the Pre, Post, and Follow-Up Time Periods .... 28

2 Mean Multiple Affect Adjective Checklist Scores at the Pre, Post, and Follow-Up Time Periods . . 32

3 Mean Tennessee Self Concept Scale Scores at the Pre, Post, and Follow-Up Time Periods. . . . 35 


\section{CHAPTER I}

\section{INTRODUCTION AND LITERATURE REVIEW}

Genital herpes has climbed from relative obscurity to one of the most infamous sexually transmitted diseases in today's society (Raab \& Lorincz, 1981). The Center for Disease Control in Atlanta, Georgia reported in 1976 that genital herpes is the second most common sexualiy transmitted disease (gonorrhea being first) and is quickly closing the gap (Hime11, 1981). More recently, the Center estimated that the number of new cases of herpes genitalis is approximately 300,000 per year with these estimates approaching 500,000 new yearly cases cited by some researchers (Suimaya \& U1lis, 1980).

Current popular 1iterature from Reader's Digest (February, 1982), Newsweek (February, 1982) to Changing Times (October, 1981) and New Times (June, 1978) have added to the recent wave of interest. Not only have these references to genital herpes in the media stimulated public interest, but it has been suggested by Langston (1983) that the press coverage and "sensationalism" have also been sources of anguish for the herpes sufferers. Accurate information is needed by both those afflicted with genital herpes as well as the general public to more fully understand the nature and effects of this viral disease.

Genital herpes is only one of the five types of the human herpes virus group. Varicella zoster (VZV) is the herpes virus responsible for chicken pox in children and shingles in adults (LeClaire, Zaia, \& Levin, 1980). Epstein-Barr virus (EBV) is an agent in infectious mononucleosis (Henle \& Henle, 1979). Cytomegalovirus (CMV) is a major 
cause of disease among newborns and is second only to Down's Syndrome as a cause of congenital mental retardation in infants (Nahmias, 1981). In adults, cytomegalovirus is a major cause of morbidity and mortality in kidney, heart, and bone marrow transplant patients (Nahmias, 1981). Herpes simplex virus type 1 (HSV -1 ) is the causative agent in the common cold sore and fever blisters and Herpes simplex virus type 2 (HSV-2) is the virus most closely associated with genital herpes. However, with the increasing incidence of oral-genital sexual contact, both HSV -1 and HSV-2 can be the etiologic organisms in herpes genitalis (Raab \& Lorincz, 1981 ).

Herpes viruses are ubiquitous and some researchers estimate as many as $95 \%$ or more of the adult population have been infected with at least one member or more of the human herpes virus group (Hirsch, Cheeseman, \& Hammer, 1979). Most of the initial infections of HSV-1 were acquired in early childhood, usually from a close relative kissing the child when an active coldsore was present (Corey, 1982). All of the herpes simplex viruses (both HSV-1 and HSV-2) are transmitted through direct physical contact either with physical touching (autoinoculation can result from transferring the virus to another part of one's body from the original site of infection), kissing, or sexual intercourse.

Fortunately, most of the herpes viruses remain latent for many years, possibly for the life of the individual (Hirsch, et al., 1979). However, the containment of the virus requires constant vigilance by the body's immune systems, and any disruption in the immunological responsiveness can stimulate viral activation or reactivation in the host. In some individuals herpes virus can lead to severe physiologi- 
cal and psychological complications (Hirsch, et al., 1979).

Hirsch, et al. (1979) provides a summary of the possible physical complications. For example, HSV-l is the most common cause of fatal, non-epidemic viral encephalitis in the adult population. HSV-2 may cause herpetic meningitus causing distressing headaches and nuchal rigidity. Additionally, both HSV-1 and HSV-2 may invade the eye tissue causing severe scarring of the cornea known as herpes keratitis. Herpes keratitis is the leading cause of blindness in young adults and results in more corneal transplants than any other causative agent.

Genital herpes may be transmitted to the newborn usually during the passage through the birth canal of the mother when an active lesion is present. Neonatal herpetic disease can be devastating and in $50 \%$ of the newborns with disseminated herpes the central nervous system is affected. In these cases, there is a mortality rate of $80 \%$ (Nahmias, Josey, \& Naib, 1971; Perley \& Bills, 1983).

One of the most publicized complications of herpes simplex virus is the association of genital herpes with cervical carcinoma (Rosenthal, 1979). Dr. W. E. Rawls at the Baylor College of Medicine found evidence that twice as many women with genital herpes had cervical cancer than the control group (Rawls, Tompkins, Melnick, 1969). More recently, Dr. Andre Nahmias of Emory University School of Medicine reported that women who suffer from genital herpes may have as much as an eight times greater risk of developing cervical cancer than women without genital herpes (Nahmias, 1974). 
It is little wonder then that a diagnosis of genital herpes can be very traumatic for some individuals, with psychological complications being concommitant with the disease. In 1979, the American Social Health Association mailed out a six-page questionnaire to its 7,500 members. This questionnaire was designed in part to assess the psychological impact of genital herpes. Over $40 \%$ of the questionnaires were returned $(n=3148)$. The overwhelming majority of the respondents reported experiencing depression ( $84 \%$ ), feelings of isolation, lowered selfesteem, stress, anxiety, sexual dysfunctioning, and some stated having suicidal thoughts as a result of having contracted genital herpes (ASHA, 1981).

In an article reviewing the psychiatric aspects of a variety of infectious diseases, Schwab (1982) reported a relationship between infectious diseases and mental health. Due to the recurrent nature of genital herpes, he noted that some individuals have difficulty making stable psychological adjustments. Specifically, changes in the body due to genital herpes and the related lesions can affect one's view of physical attractiveness with the result being a lowered body image. Additionally, Schwab indicated the self-concept can become flawed as the herpes sufferer attempts to cope with such feelings as: denial, fear, depression, and anger. Without qualification, Schwab stated, "patients with genital herpes are in need of psychotherapy" (Schwab, 1982).

Katcher, Brightman, Luborsky, and Ship (1973) conducted an interesting study on nursing students with recurrent herpes labialis (RHL) or oral herpes. They attempted to predict the incidence of RHL using various psychological measurements. It was found that the Unhappy 
factor on the Clyde Mood Scale had significant independent correlation coefficients with RHL incidence. This same result was noted by Luborsky, Mintz, Brightman, and Katcher (1976) who conducted a similar study with nursing students. They concluded that "those who judged themselves as more typically unhappy tended to have more RHL during their first year of nurses' training.." In a clinical study investigating the natural history of recurrent episodes of genital herpes (Guinan, MacCalman, Kern, Overa11, \& Spruance, 1981), 27 women were clinically studied from the first onset of a recurrence of genital herpes until the next recurrence appeared, or two months later, whichever came first. Over onehalf of the women reported that emotional stress precipitated and triggered a subsequent herpes outbreak.

Goldmeier and Johnson (1982) monitored 58 patients with primary attacks of genital herpes over the course of 30 weeks. They administered the General Health Questionnaire which is a self-administered test of 60 items questioning feelings and behavior designed to assess "nonpsychotic psychiatric illness." Patients with scores over 11 are defined as "potential psychiatric cases." They found that 29 patients with a General Health Questionnaire score over 11 had a significantly higher recurrence rate of genital herpes than the 29 patients with a score below 11. They concluded that non-psychotic states, such as anxiety and obsessionality, may reactivate the herpes virus and suggest that a chemical or psychological approach to treatment could be used to modify the autonomic responses to the emotional states. Additionaliy, Juel-Jensen (1973) suggested that "emotional upset may be a factor causing reactivation of latent infection possibly due to the release of adrenal ine." 
A unique relationship between depression and herpes simplex virus has been proposed by Cappel, Gregoire, Thiry, and Sprecher (1978). They reported that a higher prevalence of herpes simplex antibodies was found in patients with psychotic depression than in those with other psychiatric diseases or control groups. They suggested a causative link between depression and herpes simplex virus. In fact, Cappel et al. strongly suggested that a latent herpes simplex virus infection lying dormant in an undefined area of the brain "might be responsible for some psychiatric disease."

Recognition of the need for emotional support for herpes sufferers is becoming more wide-spread in the medical community. A recent article by Lynch (1982) addressed the nursing professionals and indicated the necessity to provide psychological support for those coping with this disease. She also noted that psychological repercussions of herpes infections trigger such emotions as frustration, depression, and the feeling of "why me?" In fact, Lynch noted that these emotions experienced by herpes victims are similar to those experienced by patients with any chronic disease.

Questions remain regarding the etiology and relationship between depression and herpes simplex virus. However, it is widely recognized in the literature that psychological complications can arise from genital herpes. Of paramount concern is the prevalence of depression among herpes sufferers as evidenced by clinical cases, anecdotal information, and questionnaire sources and the need to help those afflicted cope in an adaptive way.

Gillespie (1982) refers to the process of coping with genital 
herpes as a "process of adjustment" to the physical and emotional elements and living with the possibility of occasional disruptions in sexual freedom and spontaneity. He has outlined three ascending degrees of psychological reaction to recurrent herpes outbreaks. The first degree is a minor reaction where recurrences only temporarily and mildly affect the individual's personal life. The second degree typifies those who may suffer more frequent outbreaks, but have accurate information and counseling and are capable of adjusting accordingly with a minor discomfort to daily life. The third degree of psychological reaction is more serious with increases in fears and anxieties which can present a real and sometimes severe difficulty in adjustment. As Gillespie aptly stated it, "the real danger lies in letting the emotional syndrome become more powerful and recurrent that the rash itself."

Hamilton (1980) in his famous work entitled The Herpes Book outlines an approach to use in coping with genital herpes. This technique is called the "ABC Approach" wherein A refers to improving one's overall attitude and self-esteem, B looks at behavioral changes in coping with the herpes virus, and $C$ is the constitution or overall health of the individual. He discusses at length the need to overcome the psychological complications and proposes that in many cases individual psychotherapy is necessary. Hamilton's form of treatment for herpes sufferers is similar to a model described by Annon (1976) in the behavioral treatment of sexual problems. However, Hamilton stresses the need to change cognitive factors as well as behavioral adjustments, an emphasis which is characteristic of those forms of therapy more typically subsumed under the philosophy of Cognitive-Behavioral therapies (Meichenbaum, 1977). 
Other forms of therapy for herpes sufferers have been suggested in the literature. Langston (1983) reported that group psychotherapy provides an excellent medium for reducing the herpes victims' feelings of isolation as they "unite" with others facing similar adjustments. Through the guidance of the therapist, group members are provided continuous reinforcement and group pressure to improve self-esteem as well as opportunities to release inner tensions. Langston also suggested that the feelings of depression, frustration, anger, guilt, and helplessness commonly found among herpes sufferers can become moderated within the cohesion of a psychotherapy group.

Self-help groups have been recognized as a viable alternative to the directed psychotherapy groups (Lieberman, 1979). As stated in Gartner and Riessman (1982), self-help groups are defined as "voluntary small group structures for mutual aid in the accomplishment of a specific purpose." The number of self-help groups has grown tremendously during the past decade with an estimated 500,000 groups being reported to be in existence across the United States (Gartner \& Riessman, 1982). There are self-help groups available for almost every disease listed by the World Health Organization as well as a number of groups developing for a wide range of psychological concerns (Gartner \& Riessman, 1982). According to the summer, 1984 edition of the The Helper, published by the American Social Health Association, there are 81 self-help groups for herpes victims across 36 states (including the District of Columbia). Woddis (1983) investigated the benefits of six self-help groups for herpes sufferers in England. She noted that self-help groups can 
be a "life-line" for those coping with genital herpes due to the high risk associated with damaging long-term emotional and psychological effects upon the victim's self-esteem, self-image, and sexuality. For example, Woddis reported many herpes victims suffered from both lack of information and misinformation regarding genital herpes. Psychological complications can arise with feelings of "being tainted and dirty," feelings of being social outcasts, and isolated from support networks. Woddis suggested the benefits to self-help group participation partly arise from the sense of being accepted, provision of moral support, and the knowledge that the herpes sufferer is not alone with this affliction.

Although the evidence that psychological complications can be concomitant with the physical aspects of genital herpes is growing, there is a paucity of research which assesses the nature and extent of psychological distress. No controlled study could be found which attempted to measure the level of psychological discomfort and then provide any treatment intervention to modify the psychological complications. Therefore, this clinical study was proposed to fill part of the gap found in the clinical research literature.

Three groups of female subjects $(n=18)$ who had been diagnosed by the medical profession as having genital herpes were used in this study. Due to the extra complications and risks associated with women who have genital herpes, only adult female subjects were used in this study. The three groups were: 1) Group Therapy Treatment: 2) Self-Help Control; and 3) No Treatment Control. Assignments of subjects to one of the three groups was based upon self-selection. There was considerable difficulty in locating subjects who were interested in participating 
in group therapy. As a result, the subjects had to be self-selected and no random assignment to the treatment groups could be made. Since the possibility of introducing systematic errors in this study is strong, cautious interpretations of the results must be made.

Those women who wanted group psychotherapy and who successfully completed a screening examination were assigned to the Group Therapy Treatment group. Women who had attended at least two of the monthly meetings of a local self-help group within the six months preceding the study were placed into the Self-Help Control group, and those women who volunteered to be a part of the clinical study, but who did not desire any form of treatment, were assigned to the No Treatment Control group.

The clinical study took place over a sixteen (16) week or 4 month period. All members of each group received a psychological battery of tests at the onset of the study as a baseline measure (pretest), during the eighth (8) week (posttest), and during the sixteenth (16) week (follow-up). The Self-Help group and the No Treatment group were used as control groups as a comparison against the Group Therapy Treatment group. The Group Therapy Treatment group received weekly two-hour group therapy sessions for eight (8) consecutive weeks.

This study was designed to ask the following questions: 1) what is the degree of psychological discomfort associated with genital herpes as assessed by the selected psychological measurements; 2) if there are psychological complications, is group psychotherapy an effective mode of treatment as compared to the two control groups and also compared to the Group Therapy Treatment group baseline; and 3) if there are positive 
changes as a result of undergoing group psychotherapy, will this benefit last over time?

Predictions were made that the Group Therapy. Treatment group and the Self-Help Control group would show some level of psychological distress at the beginning of the study and that some decrease in this level of distress would be noted at the end of the eighth week (posttest). It was also expected that the Group Therapy Treatment group would show a higher level of improvement at the end of the eight-week group psychotherapy treatment than the Self-Help Control group during this same assessment period.

Additionally, it was predicted that the No Treatment Control group would show less psychological discomfort at the beginning of the study as compared to the other two groups and maintain a similar level of adaptation throughout the entire period of investigation. It was also expected that the improvement predicted for the Group Therapy Treatment group at the end of eight weeks of group psychotherapy would remain fairly constant during the follow-up assessment period. 


\section{CHAPTER II}

\section{METHOD}

\section{Subjects}

A total of 26 subjects were initially chosen to participate in this study. However, due to some known and unknown factors, the actual study consisted of 18 subjects. The attrition rate had the most impact on the Group Therapy Treatment group reducing the original number of participants from 9 to 4 who actually participated throughout the entire clinical study. Two subjects dropped from the Group Therapy Treatment group due to changes in work schedules, one for family-related problems, one moved out of state, and one subject's data was dropped from the analysis due to erratic attendance during the treatment phase. For all groups, data will be reported only for those subjects who completed the entire project throughout all phases of the study.

In the actual study, a total of 18 subjects participated. A11 of the subjects were white females ranging in age between 26 and 47 (mean age, 33 years). Additionally, all of the subjects had been diagnosed by the medical profession as having genital herpes. The duration of herpes contraction for each group is as follows: Self-Help Control group -- Range of 1.5 years to 13 years (mean 4.8); No Treatment Control group -- Range of 1.5 to 11 years (mean 4.8); Group Therapy. Treatment -- Range of .5 to 9 years (mean 3.2). There were a total of 8 subjects in the Self-Help Control group, 6 subjects in the No Treatment Control group, and 4 subjects in the Group Therapy Treatment group. 
Subjects were solicited from the following sources: Oregon Health Sciences University--Department of Microbiology and Immunology; Multnomah County Health Department; Kaiser-Permanente Health Care Center; Planned Parenthood Association; Craig Walker-KGW radio program; Women's Health Center; 1982 Herpes Symposium at the Oregon Health Sciences University; and advertisements in the Portland State University Vanguard and the Willamette Weekly.

\section{Materials}

Specific tests were chosen to measure the degree of adjustment on the emotional responses of: depression, anxiety, and physical selfesteem. These emotional responses were noted on the national survey conducted by the American Social Health Association of herpes sufferers (ASHA, 1981). The most noted psychological distress reported by many references is depression. Therefore, this study was attempting to have the most positive effect on this area of psychological discomfort. The psychological battery of tests consisted of the following selfadministered assessments: Beck Depression Inventory (BDI), (Beck, 1978) was the primary measurement; Multiple Affect Adjective Checklist (MAACL), (Zuckerman \& Lubin, 1965) and the Tennessee Self Concept Scale (TSCS), (Fitts, 1965) were supplementary assessments. Each battery was completed by all subjects individually.

Beck Depression Inventory (BDI)

The BDI is a widely employed self-administered depression scale which is frequently used in clinical assessment studies. In addition, it has been shown to have significant correlation to other depression assessments, e.g., MMPI, Hamilton Rating Scale, and Raskin Scale (Beck, 
Rush, Shaw, \& Emery, 1979). Furthermore, the BDI is a versatile instrument in its assessment of trait and state conditions of depression through slight alterations in the instructions given to subjects. In this study, subjects were asked to complete the BDI according to how they had been feeling in the past week, including today, to give a measure of the state condition of depression. Multiple Affect Adjective Checklist (MAACL)

The MAACL is available in two forms: General and Today. The General form asks the subject to respond describing how s'he generally feels, while the Today form solicits responses of how s'he feels now or today only. The General form was chosen to assess the trait condition of the subjects. The MAACL provides scores on three affects: anxiety, depression, and hostility. For purposes of this study, data are provided only on the anxiety scale.

Tennessee Self Concept Scale (TSCS)

The Clinical and Research form of the TSCS was used in this study. This form of the TSCS was selected because several discrete areas of self-esteem can be assessed. The subscale describing the Physical Self was chosen and data on this subscale will subsequently be reported.

\section{Procedure}

No Treatment Control Group

Subjects for the No Treatment Control group were solicited at a national Herpes Symposium conducted at the Oregon Health Sciences University in April, 1982. A sign-up sheet was prepared and posted asking for participants in a herpes research project being conducted 
at Portland State University. Subjects enlisted for this control group consisted of those females who reported a willingness to participate in a research project for assessment only. In other words, control subjects did not indicate a willingness to participate in any form of treatment, either self-help or group therapy sessions.

Prior to the actual beginning of the study, consent forms were mailed to a 11 subjects (See Appendix A). Included with the consent forms were Screening Interview questionnaires (See Appendix B) designed to provide the following information: name of subject, age, length of herpes contraction, nature and type of diagnosis, as well as general medical and psychological information. Please refer to Appendix B for further details. Each subject was instructed to provide a code number (the last four digits of their social security numbers) to be used on all test materials to assure confidentiality throughout the entire clinical study.

Pretest. Pretest measurements were obtained by mailing the psychological battery to the homes of the participants. Self-addressed, stamped envelopes were provided by the researcher to facilitate the return of the test materials. Originally, eight (8) individual batteries were mailed, but two (2) subjects failed to respond in a timely manner and their data were subsequently dropped from the study. A11 remaining subjects returned the test materials within one week after they were initially mailed $(n=6)$.

${ }^{1}$ This clinical study was approved by the Human Subjects Review Board at Portland State University to assure the safety and protection of all participating subjects. 
Posttest. During the eighth (8) week of the study, the same battery of psychological assessments were mailed to the subjects. As before, stamped envelopes were provided and instructions given which asked the subjects to respond within 24 hours of receiving the test materials. All of the six subjects who had responded to the pretest measurements returned the test materials during the posttest assessment period. A11 of the batteries of tests were returned to the researcher within a seven-day period. In one case, the researcher telephoned one subject after five (5) days and was informed that the subject had mailed the test materials the previous day. This data was obtained within the necessary seven-day time period which was consistent with the other subjects within the No Treatment Control group.

Follow-up. The same battery of test materials was sent to all subjects during the sixteenth (16) week from the start of the study. Consistent with the two previous assessment periods, subjects were once again instructed to respond within 24 hours and to return the materials in the stamped, self-addressed envelope. All subjects $(n=6)$ responded and the test materials were received within one week. Included with this last battery of tests, the researcher attached a letter of appreciation for each subject who had participated in this clinical study. Self-Help Control Group

Self-help meetings for persons coping with genital herpes are held monthly at the Providence Medical Center in Portland, Oregon. Subjects were solicited after the researcher attended one monthly meeting and announced the research study being conducted at Portland State University. After the details and nature of the study were explained, 
the researcher asked for female volunteers to participate and a list of names was obtained. Subjects were included if they met two criteria:

1) that subjects in the self-help group considered themselves regular attenders of the monthly self-help meetings; and 2) that each subject had attended at least two of the six possible monthly meetings during the previous six-month period prior to the outset of the study. All of the nine (9) subjects chosen for the Self-Help Control group satisfied both criteria.

Consent forms were mailed to the participants in the Self-Help Control group prior to the beginning of the research project (Appendix A). Included with the consent form was the Screening Interview mentioned previously (Appendix B). Each subject was instructed to use the standard subject code number on all subsequent correspondence and test materials to assure privacy.

Pretest. During the first week of the clinical study, all subjects were mailed the first battery of psychological tests. To help insure the return of the test materials, a stamped, self-addressed envelope was included with each test battery along with instructions to complete and return the requested information within 24 hours upon receipt. Of the nine (9) subjects included in the Self-Help Control group, all but one returned the test materials within a one-week period. The one subject who did not return the materials did not respond even after a telephone reminder from the researcher. Therefore, this subject was dropped from the Self-Help Control group leaving a remainder of eight (8) subjects who remained participants throughout the entire study period. 
Posttest. The original battery of tests was mailed to each subject again during the eighth (8) week into the study. Each subject was provided with the stamped envelope and instructions to again respond within 24 hours of receiving the test materials. During this phase of the clinical project, all subjects $(n=8)$ returned the requested information within a seven-day period.

Follow-up. During the sixteenth (16) week from the beginning of the study, each subject was sent the same three psychological tests to complete for the last time. Similar instructions were provided to all subjects to return the test materials in the provided envelope within 24 hours. A letter of appreciation was also included with this last packet of test materials thanking each subject for her participation. Two subjects initially failed to respond by the fifth day after the materials were mailed to them. The researcher telephoned each of these two subjects and received verification that the psychological assessments had been completed within the 24-hour period, but had not been mailed. This material was received within the following two days and included in the data analyses $(n=8)$.

Group Therapy Treatment Group

The Group Therapy Treatment group consisted of women who contacted the researcher, who chose to participate in group psychotherapy, and who successfully completed a screening interview. The screening interviews were conducted by the researcher with every potential treatment group subject. These interviews were held at Portland State University and were designed to screen and exclude those persons who might not be stable enough to endure group therapy. Strict attention was paid by the researcher to exclude anyone who displayed such personality character- 
istics as: reality distortions, hostility towards the researcher, antisocial personality disorders, or any other obvious factors that would ensue risk for either the individual or the group as a whole. A total of eleven (11) women were interviewed. Two women were dropped from the study because one subject had extensive medical problems unrelated to genital herpes and the second woman demonstrated severe personal and psychological instability. This second potential subject was referred to an appropriate psychological program by the researcher at the end of the screening interview. Therefore, a total of nine (9) subjects were included in the Group Therapy Treatment group.

Once a volunteer had been accepted for the study, a full disclosure of the purpose of the study and all pertinent information was given. All questions posed by the subjects were answered and no attempt at disguise was made. Once each subject was completely familiar with all aspects and demands of the study, a written consent form was presented and signed. All information obtained for each subject was subsequently assigned a subject code number to assure the confidentiality and privacy of each participant.

Each subject was informed that her attendance was required once a week for a two-hour group psychotherapy treatment for eight (8) consecutive weeks. Additionally, subjects were informed that psychological assessments would be taken at the completion of the eight-week therapy program and again after a subsequent eight-week follow-up period. The subjects were not charged for the provision of group psychotherapy and no costs except for transportation were incurred by the participants. 
Pretest. Prior to the actual group formation, all subjects $(n=9)$ met in a classroom where the first set of psychological tests was administered individually to all group psychotherapy participants. Upon completion of these assessments, the group was taken to the Counseling Department at Portland State University where group psychotherapy treatment was provided. During the following eight (8) weeks all treatment sessions were also held in the same room. Group Psychotherapy Treatment. The style of group psychotherapy treatment followed a Cognitive-Behavioral theoretical perspective as outlined by Meichenbaum (1974, 1977) and reported in Kendall and Hollon (1979). However, the specific model of therapy provided was adopted from Hamilton (1980) as outlined in his book entitled, The Herpes Book. It will be recalled that Hamilton refers to this form of treatment as the "ABC Approach" wherein A refers to improving one's overall attitude and selfesteem; B looks at behavioral changes in coping with genital herpes; and, $C$ is the constitution or overall health of the individual. An outline of this approach and the main categories is provided in Appen$\operatorname{dix} C$.

Consistent with the Cognitive-Behavioral perspective, each group psychotherapy session had a specific task and "home-work" assignment designed to provide direction and to facilitate behavioral and cognitive changes. Many of these homework assignments were adapted from Napoli, Kilbride, and Tebbs (1982) and the reader is referred to this source for the specific details of these assignments. In addition, each group member was provided with a personal journal in which they were instructed to record feelings, questions, specific behaviors, or 
any concerns which needed to be addressed within the group therapy sessions. However, special emphasis was not placed on these journals and with the exception of encouragement to use this medium for expression, the journals were respected as private material to be used at the discretion of each therapy member.

It is difficult to capture individual and group interactions and the dynamics of each group therapy session. However, to illustrate the main components of each session, and to facilitate a fuller understanding of the specific directions of this therapy, the directed tasks for each therapy session will be briefly highlighted below. At the conclusion of each treatment session, ten (10) minutes of stress management (via audio relaxation tapes) was introduced.

Group Therapy Session 1. During the initial group meeting, the first part of the session consisted of members getting acquainted with each other. To facilitate this, each member wore a name tag, and the larger group was split into smaller groups of two members each. The purpose of these smaller groups was to provide an opportunity for each group member to "interview" a partner and then to introduce the partner to the reconvened larger group.

The second half of this first group meeting consisted of discussing group rules (i.e., smoking, breaks, confidentiality, etc.) and handing out individual journals. The specific "homework" task was to respond to the following inquiries at the next group session: 1) reasons for joining the group; 2) goals to attain; and 3) what each hoped to gain from participating in group psychotherapy. 
Group Therapy Session 2. Group members discussed their responses to the above three questions posed the previous week. The researcher proposed and outlined the "ABC Approach" (please refer once again to Appendix $C$ for the outline of this approach). The relaxation exercises conducted at the end of each session as outlined by Brown (1977) were one component of the "ABC Approach." Group members were given data sheets with instructions to gather the required information during the following week (See Appendix D). These data sheets were designed to assess and measure the level and source of distress over a one-week period as well as to highlight all positive behaviors, i.e., stress management and physical exercise. Three subjects failed to attend this session reducing the total participants to $n=6$. Group Therapy Session 3. Group discussion was held regarding the data sheets and individual patterns of distress were noted and discussed. One subject failed to complete the required data sheet, but fully participated in a discussion regarding the nature of distress and the source of irritation and was easily able to relate a11 forms and type of exercise performed the previous week from memory. The "ABC Approach" was again presented and reviewed as this was an integral part of every therapy session. The second half of the group meeting consisted of a presentation by the researcher on the nature of physiological responses to the herpes virus. 
Group Therapy Session 4. The didactic presentation of the herpes virus and the physiological reactions was reviewed and continued. The purpose of this detailed presentation on the nature of the disease, including the transmission of the virus as well as the latency and recurrence possibilities, is an inherent component of the "ABC Approach", gathering accurate information. Parenthetically, it was noted by the researcher that many group members held a variety of misconceptions and myths about genital herpes which were clarified during the follow-up discussion.

The second half of this session involved assigning a "homework" task entitled, "Emotional Assessment" (Refer to Napoli, et al., 1982). Briefly, subjects were instructed to indicate one specific emotion which was of concern and to then analyse under what circumstances this emotion was triggered. Group Therapy Session 5. The first half of the two-hour session consisted of reviewing the material gleaned from the previous week's assignment, "Emotional Assessment." The "ABC Approach" handout was again reviewed and discussion solicited on every component of this model. A follow-up assignment was given entitled, "Emotional Modulation" (Napoli, et al., 1982) to be completed for the next therapy session. This module was designed as a counterpart to "Emotional Assessment" with emphasis on changing one's behavior and reaction to the specific emotion targeted. (It may be interesting to note that the emotion specified by the majority of group members was anger). The remainder of this therapy session was completed with stress management with a tenminute relaxation tape being played prior to group dismissal. 
Group Therapy Session 6. The first part of this therapy session consisted of group discussion over the module, "Emotional Assessment." Personal issues were discussed and members provided guidance and suggestions on further means to change "problem" behaviors and reactions. At the core of this session, group discussion was also evident on the "ABC Approach" with a noted emphasis on concerns related to self-esteem. Members of the therapy group were given a new handout entitled, "Self-Esteem" (Napoli, et al., 1982) as their next week's assignment. This particular handout was a direct attempt to have each group member assess those circumstances and individuals who have had either a positive or negative impact on her self-esteem. Additionally, this didactic assignment also emphasized outlining those abilities and accomplishments which could enhance one's self-image and maintain it at a reasonably high level. Therapy ended as usual with a ten-minute relaxation audio tape. One subject contacted the researcher prior to this session and dropped out of the study due to work-schedule conflicts reducing the group size to five (5). Group Therapy Session 7. Discussion was prompted by the completion of the module, "Self-Esteem." Two group members appeared to have had a difficult time identifying positive characteristics and group support and modeling was provided for them. A review of the components of the "ABC Approach" was once again discussed. The last assignment that was given to group members to review during the following week was entitled, "Self-Instruction for the Regulation of Anger" adapted from Novaco and reported in Kendall and Hollon (1979). This material provided subjects with a means 
for anticipating an anger provocation, information on how to moderate the impact and confrontation, coping with the emotional arousal, and subsequent reflection based upon one's response in the anger-provoking situation (Refer to Kendall and Hollon, 1979, for the specific elements of this handout). Group Therapy Session 8. During this last therapy treatment, emphasis was placed on reviewing the material on "Anger" as well as a general review of the specific information given during previous therapy sessions. A review was also discussed of the "ABC Approach" and each member reflected upon how she would continue to implement behavioral and cognitive changes via stress management, nutrition, exercise, and positive approaches to 1 ife in the future.

Posttest. At the conclusion of the eighth (8) week therapy session, each group member was presented with the same battery of psychological tests. After completion of the test materials, all subjects agreed to reconvene eight weeks from the last therapy date to complete the last set of questionnaires $(n=5)$.

Follow-up. Prior to the date the group was to reconvene to complete the last battery of tests, the researcher telephoned each member as a reminder of the date to meet for the follow-up assessment. All members met during the sixteenth (16) week into the study to complete the battery of psychological assessments. One member had attended the group sessions.sporadically and her test data were subsequently dropped from all data analyses. Therefore, data are reported only on the four (4) women who regularly attended all therapy sessions and completed all necessary test materials. 


\section{RESULTS}

Beck Depression Inventory (BDI)

Responses on the BDI were scored and group means and standard deviations calculated. The group means for all three groups are presented in Figure 1 (Standard deviations are found in Table 1).

As can be seen in Figure 1, both the Group Therapy Treatment group and the Self-Help Control group averaged a higher level of depression during the pretest assessment as compared to the No Treatment Control group. The mean for the No Treatment Control group on the pretest falls within the "healthy" range of depression which is generally considered to include scores falling below the measurement of 10 on the BDI. This level of adjustment found at the outset of the clinical study for the No Treatment Control group was consistently maintained throughout the entire evaluation period of 4 months. However, a marked decrease was noted in the Group Therapy Treatment group after two months of therapy as compared to both their own pretest measurement and the posttest scores obtained by the Self-Help Control group. Follow-up assessments for all three groups showed a slight decrease in measured depression as compared to the posttest interval.

A one-way ANOVA on just the pre-scores indicated that these differences were not significant $(\underline{F}(2,15)=1.65, p>.10) .^{2}$ A two-

2 Since there was concern for violating the assumption of compound symmetry in the data, nonparametric tests were also calculated, i.e., Friedman 2-way ANOVA, Kruskall-Wallis, Wilcoxen, Mann-Whitney. The patterns of results were the same and for clarity of presentation only parametric tests will be reported. 
TABLE I

MEANS AND STANDARD DEVIATIONS (SD) FOR GROUP THERAPY, SELF-HELP CONTROL, AND NO TREATMENT CONTROL GROUPS ON THE BECK DEPRESSION INVENTORY (BDI) FOR ALL PRETEST, POSTTEST, AND FOLLOW-UP ASSESSMENTS

\begin{tabular}{|c|c|c|c|c|c|c|}
\hline & \multicolumn{2}{|c|}{ PRE } & \multicolumn{2}{|c|}{ POST } & \multicolumn{2}{|c|}{ FOLLOW-UP } \\
\hline & Mean & $\underline{S D}$ & Mean & $\underline{S D}$ & Mean & $\underline{S D}$ \\
\hline $\begin{array}{l}\text { Group Therapy } \\
(n=4)\end{array}$ & 12.48 & 7.4 & 6.0 & 4.8 & 4.75 & 7.5 \\
\hline $\begin{array}{l}\text { Self-Help Control } \\
\qquad(n=8)\end{array}$ & 13.88 & 11.7 & 13.13 & 10.3 & 11.63 & 12.4 \\
\hline $\begin{array}{l}\text { No Treatment Control } \\
(n=6)\end{array}$ & 8.57 & 10.5 & 8.33 & 12.2 & 7.80 & 10.1 \\
\hline
\end{tabular}




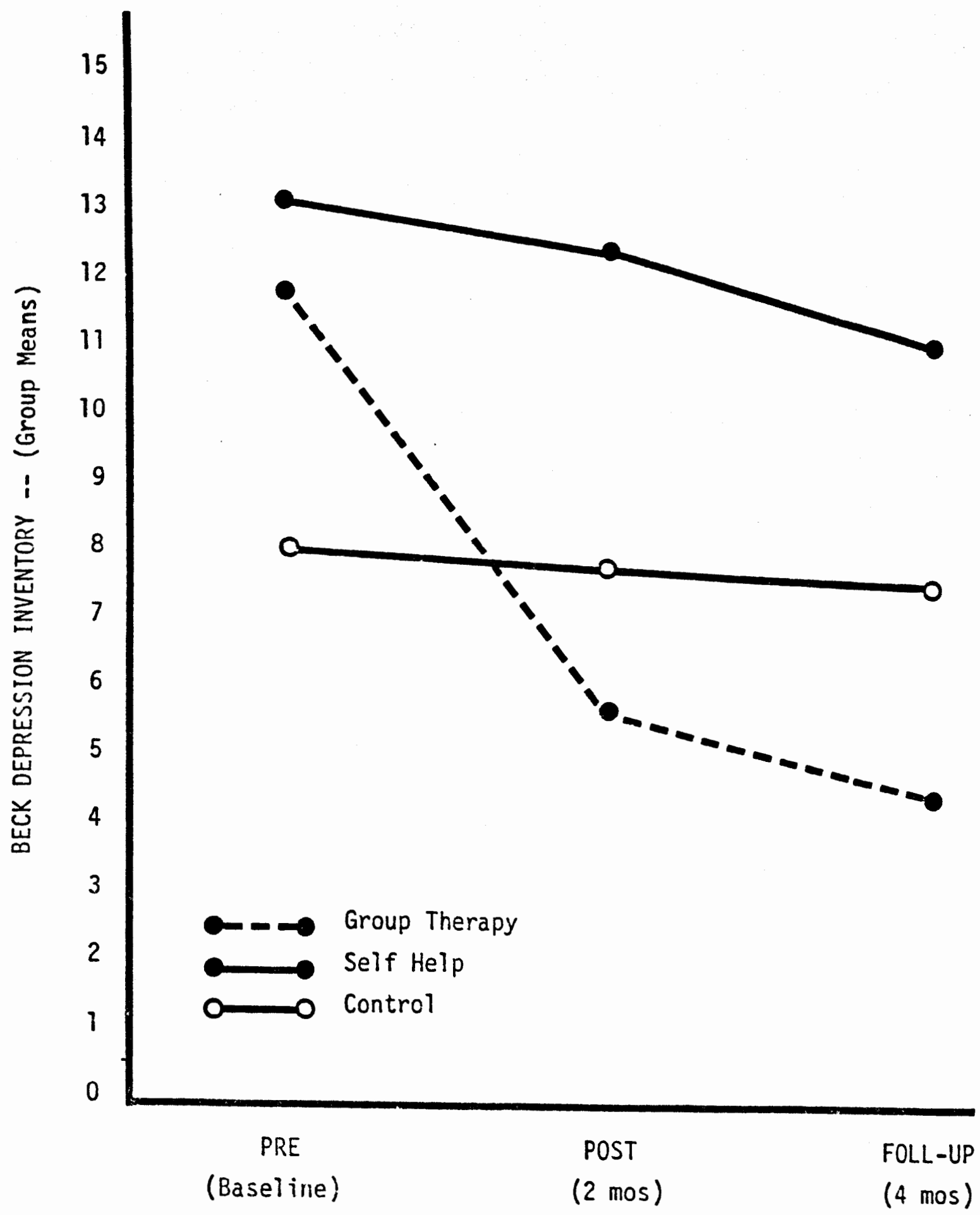

Figure 1. Mean Beck Depression Inventory scores at the pre, post, and follow-up time periods. 
factor mixed design ANOVA with repeated measures on one factor was performed on the BDI scores. The between-groups main effect was not significant $(\underline{F}(2,30)<1.0)$. However, there was a significant trials effect $(\underline{F}(2,30)=3.69, \underline{p}<.05)$ and the interaction between groups and trials approached significance $(\underline{F}(4,30)=2.22, \underline{p}<.10)$. In order to analyze the change across trials, two one-way ANOVAs including all three groups were calculated using difference scores. One compared pre vs. post scores and the second one compared pre vs. follow-up scores. On the pre vs. post comparison, there was a significant between-groups effect $(\underline{F}(2,15)=4.22, \underline{p}<.05)$. A specific planned comparison indicated that the Group Therapy Treatment group was significantly different from the Self-Help and No Treatment control groups combined $(\underline{F}(1,15)=5.79, \underline{p}<.05)$. For the pre vs. follow-up comparison, the overall difference between groups approached significance $(\underline{F}(2,15)=2.72, \underline{p}<.10)$. The follow-up planned comparison contrasting the Group Therapy Treatment group with the Self-Help and No Treatment groups combined was significant $(\underline{F}(1,15)=5.30, \underline{p}<.05)$. These results indicate that the improvement in BDI scores across trials was significantly greater for the Group Therapy Treatment group than for either the Self-Help Control or the No Treatment Control groups.

To determine if there was a significant improvement in the Group Therapy Treatment group after therapy, $\underline{t}$-tests for related means were computed. One. $\underline{t}$-test compared pre measures on the BDI with post measures. Perhaps because of the small sample size $(n=4)$, this difference was not significant, $\underline{t}(3)=2.01, \underline{p}>.10$. However, when comparing 
the improvement between pre and follow-up scores, a significant difference was noted, $\underline{t}(3)=3.78, \underline{p}<.05$. Neither the pre vs. posttest nor the pre vs. follow-up for the Self-Help Control group (t's $(7) \leq .95$, $p^{\prime} s>.20$ ), or the No Treatment Control group (t's(5) $\leq .50, p^{\prime} s>.20$ ) were significant. Multiple Affect Adjective Checklist (MAACL) - Anxiety Scale

Scores on the anxiety scale of the MAACL were obtained and the related means and standard deviations computed (See Table II). The observed differences for all three groups are displayed graphically in Figure 2, with smaller scores representing lowered anxiety levels.

Figure 2 shows a similar pattern of responses on the pretest scores to the Beck Depression Inventory, with pretests measurements for the Group Therapy Treatment and the Self-Help Control groups higher than the pretest on the No Treatment Control group. However, some increase in anxiety was observed at the posttest assessment for both the Self-Help and the No Treatment Control groups as compared to the posttest of the Group Therapy Treatment group which reflected a decrease in anxiety. Little change was found between the posttest and follow-up scores for any of the three groups.

A one-way ANOVA on the pre-scores for the three groups was not significant $(\underline{F}(2,15)=.69, \underline{p}>.10)$. A two-factor mixed design ANOVA with repeated measures on one factor was performed on the MAACL scores. The between groups main effect $(\underline{F}(2,30)<1.0)$ and the repeated measures effect were not significant $(\underline{F}(2,30)=1.22, p>.10)$. A significant groups-by-trials interaction was indicated $(F(4,30)=2.65, \underline{p}<.06)$. In order to analyze the interaction, two one-way ANOVAs were calculated including all three groups using difference scores. One ANOVA compared 
TABLE II

MEANS AND STANDARD DEVIATIONS (SD) FOR GROUP THERAPY, SELF-HELP CONTROL, AND NO TREATMENT CONTROL GROUPS ON THE

MULTIPLE AFFECT ADJECTIVE CHECKLIST (MAACL) FOR ALL PRETEST, POSTTEST, AND FOLLOW-UP ASSESSMENTS

ANXIETY SCALE

\begin{tabular}{|c|c|c|c|c|c|c|}
\hline & \multicolumn{2}{|c|}{ PRE } & \multicolumn{2}{|c|}{ POST } & \multicolumn{2}{|c|}{ FOLLOW-UP } \\
\hline & Mean & $\underline{S D}$ & Mean & $\underline{S D}$ & Mean & $\underline{S D}$ \\
\hline $\begin{array}{l}\text { Group Therapy } \\
(n=4)\end{array}$ & 10.50 & .58 & 7.75 & 2.22 & 7.50 & 2.33 \\
\hline $\begin{array}{l}\text { Self Help Control } \\
\qquad(n=8)\end{array}$ & 9.25 & 5.50 & 11.25 & 6.73 & 9.88 & 6.15 \\
\hline $\begin{array}{l}\text { No Treatment Control } \\
(n=6)\end{array}$ & 5.33 & 5.29 & 6.00 & 7.24 & 6.17 & 6.46 \\
\hline
\end{tabular}




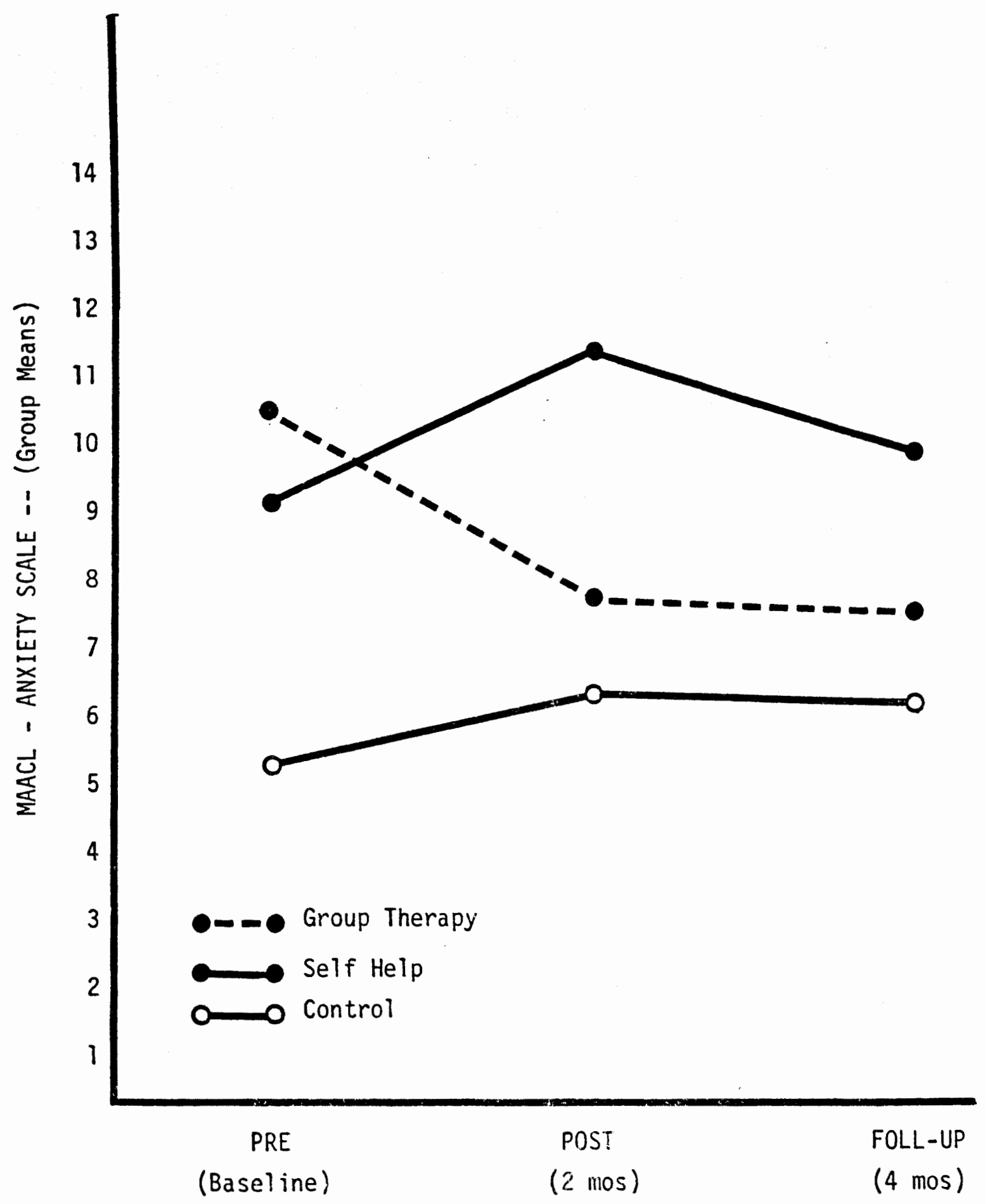

Figure 2. Mean Multiple Affect Adjective Checklist scores at the pre, post, and follow-up time periods. 
pre vs. post scores and the second one compared pre vs. follow-up scores. On the pre vs. posttest comparison there was a significant between-groups effect $(\underline{F}(2,15)=4.46, \underline{p}<.05)$. However, a specific planned comparison between the Group Therapy Treatment and the combined Self-Help Control and No Treatment Control groups was not significant. Furthermore, on the pre vs. follow-up analyses no significant differences were located. In this one incidence, non-parametric tests reflected a different pattern than the parametric comparison. Comparing the difference scores between the pre vs. posttest measurement using a Mann-Whitney test, there was a significant difference between the Group Therapy Treatment group and the combined Self-Help and No Treatment Control groups $(\underline{U}(4,14)=7, \underline{p}<.05)$. A significant difference was also noted between the Group Therapy Treatment group and the combined control groups on the pre vs. follow-up measures $(\underline{U}(4,14)=$ $9, \underline{p}<.05)$.

It is clear from Figure 2 that the significant interaction in the overall analysis reflects the fact that the Group Therapy Treatment group showed improvement across trials while the Self-Help and No Treatment Control groups got worse or stayed the same. However, it is also clear that these differences between groups on the MAACL scores were not large.

Tennessee Self Concept Scale (TSCS) -- Physical Self

Responses on Scale A--Physical Self of the Tennessee Self Concept Scale were scored and group means and standard deviations calculated. The standard deviations are listed in Table III and the group means displayed in Figure 3 , with higher scores reflecting a more positive 
TABLE III

MEANS AND STANDARD DEVIATIONS (SD) FOR GROUP THERAPY, SELF-HELP CONTROL, AND NO TREATMENT CONTROL GROUPS ON THE TENNESSEE SELF CONCEPT SCALE (TSCS) FOR ALL PRETEST, POSTTEST, AND FOLLOW-UP ASSESSMENTS

PHYSICAL SELF

\begin{tabular}{|c|c|c|c|c|c|c|}
\hline & \multicolumn{2}{|c|}{ PRE } & \multicolumn{2}{|c|}{ POST } & \multicolumn{2}{|c|}{ FOLLOW-UP } \\
\hline & Mean & $\underline{S D}$ & Mean & $\underline{S D}$ & Mean & $\underline{S D}$ \\
\hline $\begin{array}{l}\text { Group Therapy } \\
\qquad(n=4)\end{array}$ & 56.50 & 14.25 & 66.25 & 8.42 & 63.25 & 13.12 \\
\hline $\begin{array}{l}\text { Self-Help Control } \\
\qquad(n=8)\end{array}$ & 62.75 & 9.79 & 59.12 & 13.88 & 62.12 & 14.24 \\
\hline $\begin{array}{l}\text { No Trea tment Control } \\
(n=6)\end{array}$ & 68.17 & 14.23 & 69.00 & 13.95 & 71.00 & 14.76 \\
\hline
\end{tabular}




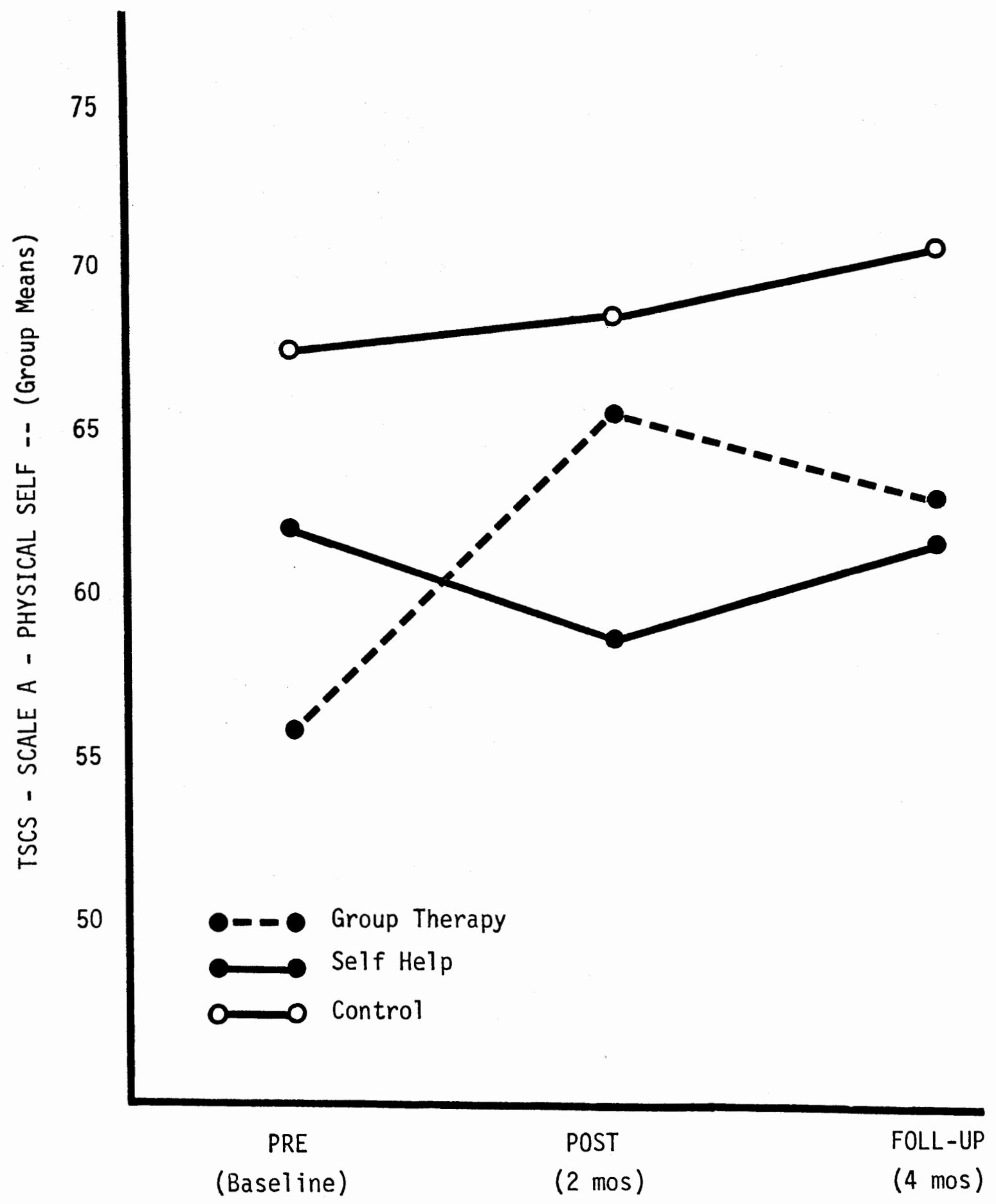

Figure 3. Mean Tennessee Self Concept Scale scores at the pre, post, and follow-up time periods. 
physical self image.

As Figure 3 indicates, the pretest measurement for the Group Therapy Treatment group was lower relative to the pretests for the two control groups. A noted increase in physical self-esteem was reflected for the Group Therapy Treatment group on the posttest measurement while a slight decrease in self-esteem was observed for the Self-Help Control group during the same time period. The No Treatment Control group varied little across the three assessment points. It must be pointed out, however, that each of the three groups at all test periods obtained scores somewhat below the "normal" level. Scores of 72 and higher fall within the normal range of physical self-esteem and only the follow-up measurement on the No Treatment Control group approached this point.

A one-way ANOVA on the pretests indicated no significant differences between the three groups $(\underline{F}(2,15)=1.10, \underline{p}>.10)$. A twofactor mixed design ANOVA with repeated measures on one factor was computed on the TSCS, Scale A--Physical Self scores. The between groups main effect was not significant $(\underline{F}(2,30)<1.0)$. The repeated measures (trials effect) was also not significant $(\underline{F}(2,30)=1.03$, $\underline{p}>.10)$. However, a significant interaction was measured $(\underline{F}(4,30)=$ $2.91, \mathrm{p}<.05)$.

To further analyze the interaction, two one-way ANOVAs were calculated including all three groups using difference scores. One ANOVA compared pre vs. posttest scores and the second ANOVA compared the data on the pre vs. follow-up scores. On the pretest vs. posttest 
comparison, a significant between-groups difference was noted $(\underline{F}(2,15)=4.10, \underline{p}<.05)$. Specific planned comparisons between the Group Therapy Treatment group and the two combined control groups also indicated a significant difference $(\underline{F}(1,15)=6.61, \underline{p}<.025)$. On the pre vs. follow-up comparison, there was no significant between-groups difference $(\underline{F}(2,15)=3.46, \underline{p}>.10)$. However, a significant difference was found between the Group Therapy Treatment group and the Self-Help Control group combined with the No Treatment Control group on the pretest vs. follow-up measurement $(\underline{F}(1,15)=5.98, \underline{p}<.05)$. These results indicate the improvement across trials in the Group Therapy Treatment group as being greater than the two other control groups. 
CHAPTER IV

\section{DISCUSSION}

The study of genital herpes is a timely issue. With the number of victims approaching epidemic proportions, the need to fully understand the physical and psychological impact on those infected grows in equal importance. This study was designed to assess the degree of psychological discomfort associated with genital herpes. Moreover, the psychological treatment intervention of group psychotherapy was implemented to assuage or reduce some of the discomfort which many of these women experienced since contraction of genital herpes.

The results of this clinical study support the process of adjustment noted by Gillespie (1982). He outlined three ascending degrees of psychological reaction from mild, moderate to what would have to be labeled a severe reaction. The first two degrees reflect temperate and relatively modest discomfort. Understandably, the severe psychological reaction, where the emotional impact is more powerful and threatening than the disease itself, is of more concern to the psychological community. To reduce the impact genital herpes has on those inflicted, Gillespie (1982) strongly suggested that some form of psychological treatment be provided.

The three groups of women in this current research project reflect the varying degrees of reactions as assessed by the three psychological tests used. Both the Group Therapy Treatment and the SelfHelp Control groups had a notably higher level of distress than the No Treatment Control group at the beginning of the study. Furthermore, 
when referring to the standard deviations within each group, individual differences suggest some of the women studied have experienced severe and dangerously high levels of distress.

Results on the Beck Depression Inventory indicated that both the Group Therapy Treatment and the Self-Help Control groups had depression scores higher than is considered in the healthy range on the pretest scores. On the BDI, the No Treatment Control group sustained a healthy level of adaptation throughout the entire study. Scores at the posttest and follow-up time periods indicated that very little improvement was measured in the Self-Help Control group. In contrast, however, the Group Therapy Treatment group had a significant decrease in the amount of depression at the completion of two months of group psychotherapy. This decrease in the amount of depression measured for the Group Therapy Treatment group placed their level of adaptation comfortably within the heal thy range. Furthermore, this improvement was maintained over time with even a slight decrease in depression noted at the follow-up period of four months.

The Multiple Affect Adjective Checklist indicated no significant differences between the three groups in anxiety level at the outset of the study. Interestingly, the Self-Help Control and the No Treatment Control groups increased in anxiety during the first two-month assessment. During the same time period, however, the Group Therapy Treatment group showed improvement after therapy and maintained this positive change across trials. When comparing the treatment group with the combined control groups, this was a significant improvement across each time period. 
The level of physical self-esteem at each assessment period was measured by the Tennessee Self Concept Scale. Although the No Treatment Control group reflected the same relative adaptive and stable pattern compared to the two other groups, it must be reiterated that even the No Treatment Control group was slightly below the considered normal level on the TSCS at all trial periods. However, it was still meaningful to measure the degree of improvement for each group in this study as any increase in self-esteem is positive.

There were no significant differences between the three groups at the beginning of the study. Some decrease in self-esteem was noted for the Self-Help Control group at the two-month interval with this slight worsening disappearing at the four-month period. The Group Therapy Treatment group showed a significant improvement in their level of physical self-esteem at the end of eight weeks of group psychotherapy. Furthermore, this significant improvement for the treatment group was held constant throughout the study as compared to the two control groups.

The results of this study lean toward the conclusion that group psychotherapy is an effective mode of treatment for some women coping with genital herpes as compared to self-help treatment and the control group who did not desire any intervention. However, there are several qualifications which must be addressed. Since it was difficult to find enough women who wanted to participate in group psychotherapy, subjects were self-selected and no random assignment of subjects was made. With no random assignment to the two treatment groups, the introduction into the analysis of systematic errors is a very strong possibility. Individual differences of subjects who volunteer or not within the design of 
the present study could lead to spurious results since there was no control over group placement. Secondly, the researcher had no information on the content of the Self-Help group meetịng, group attendance records, or discussion material. Therefore, this study only used the Self-Help group as a comparison measure.

To increase external validity, several improvements in design can be suggested. The first necessary component would be to increase the group sample size so that results could be more accurately generalized. Additionally, subjects need to be randomly assigned to one of three groups: group therapy treatment, waiting-list (control) group therapy treatment, and self-help. The two group therapy treatment groups would each receive the same length of group psychotherapy, but the waiting-list (control) treatment group would not receive therapy until after the first treatment group had completed all group psychotherapy sessions. The waiting-list (control) treatment group would serve as a comparison to assess effectiveness of group psychotherapy as well as to compare the difference in effectiveness between group psychotherapy and self-help treatment. Lastly, a fourth group--No Treatment Control, would be required to consist of those subjects who do not choose any form of treatment to assess the difference between herpes sufferers in general, or in other words, to indicate the level of adaptation for herpes victims who do not desire any form of psychological intervention. By the nature of this control group, subjects will be self-selected and not randomly assigned.

Evidence reported in the literature indicates psychological 
complications can occur along with the physical manifestations of this disease. The current clinical study was only one step in many which need to be carried out by further researchers. Although the data are not strong, for the above listed reasons, there is sufficient evidence to suggest that group psychotherapy might be a viable intervention for those coping with genital herpes. Awareness of the psychological components needs to be raised within the medical community and referrals for appropriate psychological help made. The risks for herpes victims can be too great for researchers to believe that the psychological distress concomitant with genital herpes will diminish over time without psychological treatment. An active, not a passive position needs to be taken in managing the psychological impact of the herpes virus by both the victim and the helping professionals. 


\section{REFERENCES}

American Social Health Association. (1981). The Helper, $\underline{3}$ (2), 1-16.

American Social Health Association. (1984). The Helper, 6 (2), 12.

Annon, J. (1976). Behavioral treatment of sexual problems: brief therapy. Hagerstown, MD: Harper \& Row.

Beck, A. T. (1978). Depression inventory. Philadelphia: Center for Cognitive Therapy.

Beck, A. T., Rush, A. J., Shaw, B. F., \& Emery, G. (1979). Cognitive therapy of depression. New York: The Guilford Press.

Brown, B. B. (1977). Stress and the art of biofeedback. New York: Harper \& Row.

Cappel, R., Gregoire, F., Thiry- L., \& Sprecher, S. (1978). Antibody and cell-mediated immunity to herpes simplex virus in psychotic depression. The Journal of Clinical Psychiatry, 39 (3), 266-268.

Center for Disease Control: Herpes simplex type 2. (1976). Atlanta, DHEW, Public Health Service, Publication number 00-2797.

Center for Disease Control: Herpes genital infection. (1980) Publication 00-2939.

Corey, L. (1982). The natural history of genital HSV. The Helper, $\underline{4}$ (1), $1-12$.

Fitts, W. H. (1965). The Tennessee self concept scale manual.

Tennessee: Counselor Recordings and Tests.

Gartner, A. J., \& Riessman, F. (1982). Self-help and mental health. Hospital and Community Psychiatry, 33 (8), 631-635.

Giilespie, 0. (1982). Herpes, what to do when you have it. New York: Grosset \& Dunlap.

Goldmeier, D., \& Johnson, A. (1982). Does psychiatric illness affect the recurrence rate of genital herpes? British Journal of Venereal Disease, 58, 40-43.

Guinan, M. E., MacCalman, J., Kern, E. R., Overall, J. C., \& Spruance, S. L. (1981). The course of untreated recurrent genital herpes simplex infection in 27 women. The New England Journal of Medicine, 304 (13), 759-763.

Hamilton, R. (1980). The herpes book. Los Angeles: J. P. Tarcher, Inc.

Henle, G., \& Henle, W. (1979). The virus as the etiologic agent in infectious mononucleosis. In M. A. Epstein \& B. G. Achong (Eds.), The Epstein-Barr virus. New York: Springer-Verlag, Inc. 
Hime11, K. (1981). Genital herpes: the need for counseling. Journal of Obstetric, Gynecologic \& Neonatal Nursing, 10 (6), $446-450$.

Hirsch, M. S., Cheeseman, S. H., \& Hammer, S. M. (1979). Human herpes virus infections: pathogenesis and clinical implications. In L. Weinstein \& B. N. Fields (Eds.), Seminars in infectious diseases, (Vol. 2).

Juel-Jensen, B. E. (1973). A new look at infectious diseases: herpes simplex and zoster. British Medical Journal, I, 406-410.

Katcher, A. H., Brightman, V., Luborsky, L., \& Ship, I. (1973). Prediction of the incidence of recurrent herpes labialis and systemic $i 11$ ness from psychological measurements. Journal of Dental Research, 52 (1), 49-58.

Kendal1., P., \& Hollon, S. (Eds.). (1979) Cognitive-behavioral intervention: theory, research, and procedures. New York: Academic Press.

Langston, D. P. (1983). Living with herpes. New York: Doubleday \& Co., Inc.

LeClaire, J. M., Zaia, J. A., \& Levin, M. J. (1980). Varicella zoster. New England Journal of Medicine, 302, 450-410.

Lieberman, M. A., \& Borman, L. D. (Eds.). (1979). Self-help groups for coping with crisis. San Francisco: Jossey-Bass.

Luborsky, L., Mintz., J., Brightman, V. J., \& Katcher, A. H. (1976). Herpes simplex virus and moods: a longitudinal study. Journal of Psychosomatic Research, 20, 543-548.

Lynch, J. M. (1982). Helping patients through the recurring nightmare of herpes. Nursing, 12 (10), 52-57.

Meichenbaum, D. (1974). Cognitive behavior modification. New Jersey: General Learning Press, Inc.

Meichenbaum, D. (1977). Cognitive behavior modification. New York: Plenum Press.

Nahmias, A. J. (1981). In A. J. Nahmias, W. R. Dowdle, \& R. F. Schinazi (Eds.), The human herpes viruses: an interdisciplinary perspective. New York: Elsevier North Holland, Inc.

Nahmias, A. J., \& Starr, S. (1977). Infections caused by herpes simplex virus. In $P$. Hoeprich (Ed.), Infectious diseases (2nd ed.), New York: Harper \& Row, Inc. 
Nahmias, A. J., Josey, W. E., \& Naib, A. M. (1971). Perinatal risk associated with maternal genital herpes simplex virus infection. American Journal of Obstetrics and Gynecology, 110, 825-834.

Nahmias, A. J., Naib, Z. M., \& Josey, W. E. (1974). Epidemiological studies relating genital herpetic infection to cervical carcinoma. Cancer Research, 34, 1111-1117.

Napoli, V., Kilbride, J. M., \& Tebbs, D. E. (1982). Adjustment and growth in a changing world. St. Paul: West Publishing Co.

Novaco, R. W. (1976). Treatment of chronic anger through cognitive and relaxation controls. Journal of Consulting and Clinical Psychology, $44(4), 681$.

Perley, N. Z. \& Bills, B. J. (1983). Herpes genitalis and the childbearing cycle. $\underline{M C N}, \underline{8}, 213-217$.

Raab, B., \& Lorincz, A. L. (1981). Genital herpes simplex--concepts and treatment. Journal of the American Academy of Dermatology, $\underline{5}(3), 249-261$.

Rawls, W. E., Tompkins, W. A. F., \& Melnick, S. L. (1969). The association of herpes virus type 2 and carcinoma of the uterince cervix. American Journal of Epidemiology, 89, 547.

Rosenthal, M. S. (1979). Genital herpes simplex virus infections. Primary Care, 6 (4), 517-528.

Schwab, J. J. (1982). Psychiatric aspects of infectious diseases. Current Psychiatric Therapies: 1982, 21, 225-239.

Suimaya, C. V., \& Ullis, M. J. (1980). Genital infections with herpes simplex virus in a university student population. Sexually Transmitted Diseases, $7,16-20$.

Woddis, C. (1983). Herpes genitalis--the benefits of self-help groups for sufferers. The Practitioner, 227, 865-866.

Zuckerman, M., \& Lubin, B. (1965). The manual for the multiple affect adjective checklist. San Diego: Educational and Industrial Testing Service. 


\section{APPENDIX A}

\section{Informed Consent}

I, herebv agree to serve as a subject in the research project entitled "Herpes Research Pro.iect" conducted by Sue Ferguson at Portland State University. I understand that the study involves completing psychological assessments and group therapy and that the study will demand my participation for at least four (4) months. I understand that the therapy sessions will be tape recorded and that these tapes are to be used only for monitoring purposes.

I understand that possible risks to me associated with this study are psychological and emotional discomfort associated with the group therapy. It has been explained to me that the purpose of the study is to learn if a need exists for psychological counseling, in the form of group therapy, for women coping with herpes simplex virus and, if so. will group therapy remove some of the distress associated with the viral infection.

I may not receive any direct benefit from participation in this study, but my participation may help to increase knowledge which may benefit others in the future. Furthermore, I understand that no medical services nor medical treatment will be provided.

Sue Ferguson has offered to answer anv questions I may have about the study. I have been assured that all information I give will be kept confidential and that the identity of all subjects will remain anonymous.

I understand that I am free to withdraw from participation in this studv at any time without jeopardizing my relationship with Portland State University.

I have read and understand the foregoing information.

Date Signature

If you experience problems that are the result of your participation in this study; please contact Victor C. Dahl, Office of Graduate Studies and Research, 105 Neuberger Hall, Portland State University, 229-3423. 
Dat.e

\section{SCREENING INTERVIEW}

Name:

Birthdate:

Address:

Home Telephone \# Work Telephone \#

Convenient time to call:

occupation:

Education

How long have you had herpes?

Was your diagnosis done by a physician? How was the diagnosis determined?

PAPS Smear ( ) Physical Exam ( ) Tzanck Smear ( ) Other

Describe how you were told you had herpes:

What is the primary location of your outbreaks: Genitals $(1$ Buttocks $(1$ Anus $(1$

Thighs (1) other

In the past six months, how many recurrences did you have? During the past month did you have any outbreaks? How many?

What is your predominant sexual orientation: heterosexual ( ) homosexual ( ) bisexual ( )

How many sexual partners did you have in the past year:

Are you presently living with someone? What is his/her relationship to you How long?

Have you ever had any other type of sexually transmitted disease?

Do you know the probable source of your herpes infection? What was the nature of this relationship?

How long had you known him/her Did you know he/she had herpes prior to your. contracting it? Did your relationship change with this person after having contracted herpes How?

How many people have you told about your having genital herpes?

Have you told your spouse/living companion?

$$
1
$$

Very rejecting \& Mod negative negative

$$
2
$$

3 If yes, how would you rate his/her reaction 4 5

Mod supportive Very supportive \& understanding

If no, how would you guess your spouse's or companion's reaction to be?

1

2

3

Very rejecting \& Mod negative negative

Neut:ral, but concerned
4

Mod supportive Very supportive \& understanding 
Have you told an uninfected sexual partner? Rate his/her reaction on the same scale:

\section{PSYCHOLOGICAL BACKGROUND}

Have you ever undergone psychotherapy? Length of therapy

What were your reasons for entering therapy

Have you considered any type of counseling due to herpes? Have you seen a therapist since contracting herpes? What mode of therapy did you undergo? Individual $(1$ Group ( ) Self Help ( ) Are you in therapy now? Because of herpes? If counseling were available to you now without any financial cost, would you enter therapy? What yould you hope to gain from therapy?

Have you ever attempted suicide? Because of herpes? Please explain

Have you experienced any thoughts of suicide due to herpes? (CIRCLE ONE)

$\begin{array}{ccccc}1 & 2 & 3 & 4 & 5 \\ \text { None } & \text { Rare } & \text { Occasional } & \text { Frequent } & \text { Very often \& serious }\end{array}$

How supportive or non-supportive have your friends been to you since you've gotten herpes?

1 2

Very rejecting Mod negative \& negative Have you told your parents?

1 2 3 Neutral, but concerned

4 5 Mod supportive Very supportive \& understanding What was their reaction?
5

How supportive was the doctor who diagnosed your infection?
5
1
2
3
4

What did your doctor recommend?

What are your feelings about your friends' reaction....your parents'....your doctor's?

\section{HEALTH HISTORY}

Are you presently taking any prescribed medication? If yes, please list:

How long for each:

Dosage, etc. Name (s) of your physician(s)

How often do you use/consume the following:

PLEASE CHECK ONE

Coffee

Tea

water

\begin{tabular}{|c|c|c|c|c|c|}
\hline Never & Seldom & Once/Week & Twice/Wk & Daily & Sev times/day \\
\hline & $\cdots \cdot$ & $\cdots \cdots$ & $\cdots \cdots$ & & \\
\hline$\cdots$ & $\cdots \cdots$ & $\cdots \cdots \cdots$ & $\cdots \cdots$ & $\cdots \cdots \cdot$ & $\cdots \cdots \cdots$ \\
\hline
\end{tabular}




\begin{tabular}{|c|c|c|c|c|c|c|}
\hline PLEASE CHECK ONE & Never & Seldom & Once/Week & Twice/Wk & Daily & Sev times/day \\
\hline Pop & $\ldots$ & $\ldots \ldots$ & ...... & ..... & .... & $\ldots \ldots \ldots$ \\
\hline Beer/Wine (Which?) & $\ldots$ & $\ldots \ldots$ & $\ldots \ldots$ & $\ldots \ldots$ & $\ldots \ldots$ & $\ldots \ldots \ldots$ \\
\hline Hard Liquor (Mixed drink) & $\ldots$ & $\ldots \ldots$ & $\ldots \ldots$ & $\ldots \ldots$ & $\cdots \cdots$ & $\ldots \ldots \ldots$ \\
\hline Marijuana & $\cdots$ & $\ldots \ldots$ & $\ldots \ldots$ & $\ldots \ldots$ & $\cdots \cdots$ & $\ldots \ldots \ldots$ \\
\hline $\begin{array}{l}\text { Barbi tuates } \\
\text { Other }\end{array}$ & $\cdots$ & $\cdots \cdots$ & ..... & $\cdots \cdots$ & $\cdots \cdots$ & $\cdots \ldots \ldots$ \\
\hline
\end{tabular}

How would you rate your overall health?

Very porr

- Poor

Weight

Height

2

3

4

5

How often do you do the following:

Rarely/if ever Occas.., not regular Weekly Daily Sev times/day

Calisthenics

Jogging

Aerobics

Sports

Swimming

Meditation

Relation exercise

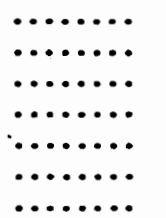

-.......

$\cdots \cdots$

$\bullet \ldots \ldots$

$\ldots \ldots \quad \ldots \ldots$

$\begin{array}{llll}\ldots \ldots & \ldots \ldots & \ldots \ldots & \ldots \ldots \\ \ldots \ldots \ldots & \ldots \ldots & \ldots \ldots\end{array}$

$\cdots \cdots \cdots, \quad \cdots \cdots, \quad \cdots \cdots$

$\begin{array}{llll}\ldots \ldots & \ldots \ldots & \cdots \cdots & \cdots \cdots \\ \ldots \ldots \ldots & \ldots \ldots & \ldots \ldots\end{array}$

$\ldots \ldots \ldots$

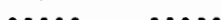

-......

Do you smoke?

How long?

How much?

Has your smoking habit changed any since contracting herpes? How?

How would you rate your overall diet?

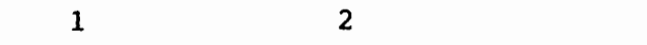

Very poor

Poor
3

Fair
4

Good
5

Excellent

Do you take any supplementary vitamins?

How would you rate your nightly pattern of sleep recently?

1

Poor-many wakings

or nightmares

2

Fitful-much tossing

What is your average number of hours of sleep per night? upon wakening?
45

Very goou Excellent

COMMENTS: 


\section{APPENDIX C}

ABC Approach

-- Adapted from R. Hamilton

\section{A: Attitudes for Good Health}

1. Accept personal responsibility for your wellness

2. Gather and read accurate information--get rid of the myths

3. Improve self-esteem--filter in all the good and not just bad

4. Control the anger and get rid of resentment

5. Turn helplessness into hopefulness

B. Behaviors for Wellness

1. Destress stress--practice stress management and reduction

2. Sidestep secondary infections

3. Avoid autoinoculation

4. Seek out good medical care

5. Wellness and others: Prevention

C. Constitutional Factors for Health

1. Nutrition--improve your diet, take vitamins if necessary

2. Sleep--be possessive of your body's rest needs

3. External environment--avoid physical stressors, i,e., sun

4. Exercise--do something different and heal thy every day 
APPENDIX D

Data Sheets for Group Therapy Treatment Group

\begin{tabular}{|c|c|c|}
\hline $\begin{array}{c}5 \\
\text { BAD } \\
\text { REACTION }\end{array}$ & 4 & $\begin{array}{c}3 \\
\text { MOD }\end{array}$ \\
\hline
\end{tabular}

TU WED THUR FRI SAT SUN MON TOTAL

8

\begin{tabular}{|l|l|l|l|l|l|l|l|}
\hline & & & & & & & \\
\hline & & & & & & & \\
\hline
\end{tabular}

10

11

Noon

1

3

4

5

6

7

8

9

10

11

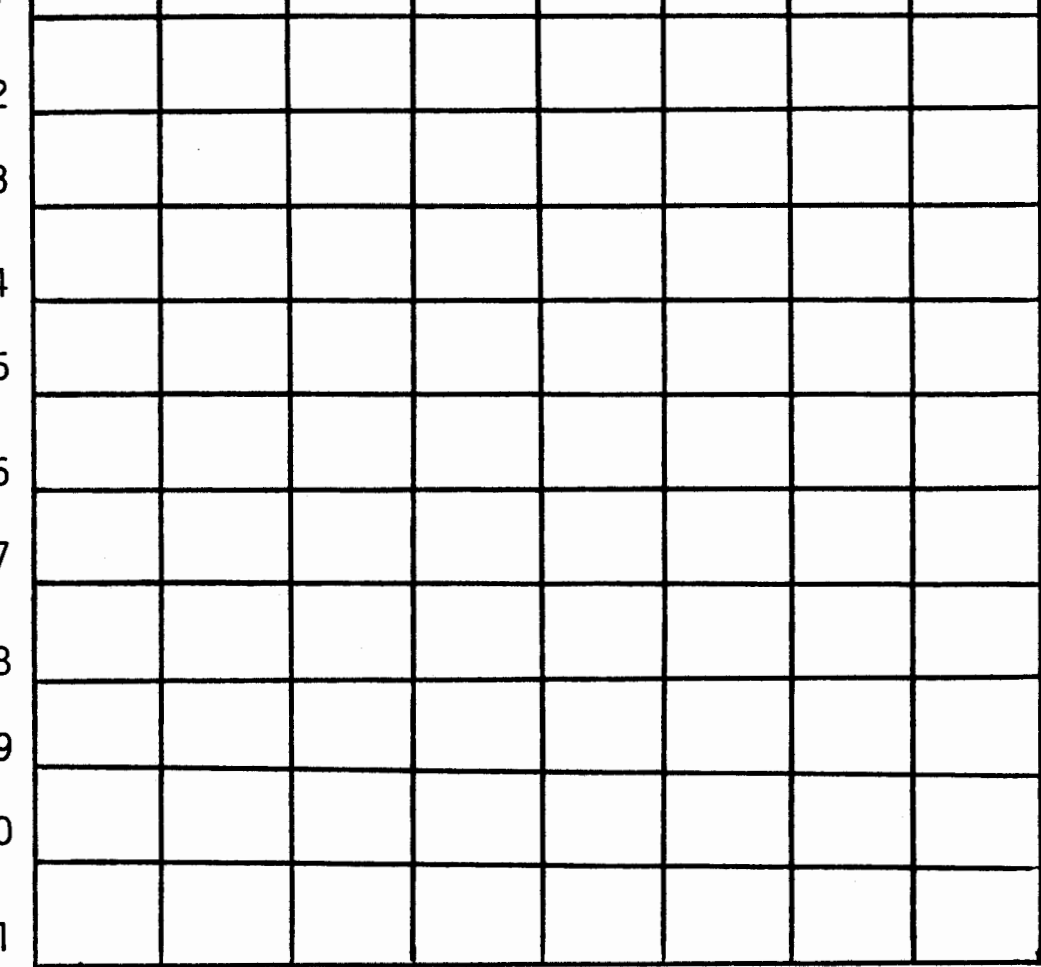

P.D. -- Physical Discomfort

C -- Care

I.T. -- Internal Thoughts

o -- Other

0.S. -- Objective Source 